\title{
AORTIC POST-RESISTANCE EXERCISE HYPOTENSION IN PATIENTS WITH PERIPHERAL ARTERY DISEASE
}

\author{
HIPOTENSÃO AÓRTICA DEPOIS DE UMA SESSÃO DE EXERCÍCIO DE FORÇA EM PACIENTES COM \\ DOENÇA ARTERIAL PERIFÉRICA
}

OIGINAL A

Original ARTICLE

ARTIGO ORIGINAL

Artículo Original

\section{HIPOTENSIÓN AÓRTICA DESPUÉS DE UNA SESSION DE ENTRENAMIENTO DE RESISTENCIA EN PACIENTES CON ENFERMEDAD ARTERIAL PERIFÉRICA}

\begin{abstract}
Marilia de Almeida Correia (Physical Education Professional) Aluísio Andrade-Lima² (Physical Education Professional)

Antônio Henrique Germano-Soares ${ }^{1}$ (Physical Education Professional)

Gabriel Grizzo Cucato ${ }^{3}$

(Physical Education Professional)

Eduardo Caldas Costa ${ }^{4}$

(Physical Education Professional)

Raphael Mendes Ritti-Dias ${ }^{5}$

(Physical Education Professional)

1. Universidade de Pernambuco, Programa de Associado de Pósgraduação em Educação Física, UPE/UFPB, Recife, PE, Brazil.

2. Universidade de São Paulo, Escola de Educação Física e Esporte,

São Paulo, SP, Brazil.

3. Instituto de Educação e Pesquisa de Israel Albert Einstein, Hospital Albert Einstein, São Paulo, SP, Brazil. 4. Universidade Federal do Rio Grande do Norte, Departamento de Educação Física, Natal, RN, Brazil. 5. Universidade Nove de Julho, Programa de Pós-Graduação em Ciências da Reabilitação, São Paulo, SP, Brazil.
\end{abstract}

\section{Correspondence:}

Rua Vergueiro, 235/249, $2^{\circ}$ Subsolo, Liberdade, São Paulo, SP, Brazil. 01504-001.raphaelritti@gmail.com

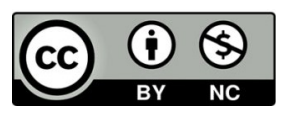

\begin{abstract}
Introduction: A single session of resistance training decreases brachial blood pressure (BP) in patients with peripheral artery disease (PAD). However, it is not known whether similar responses occur in aortic BP, which is a better predictor of cardiovascular risk. Objective: This study aimed to analyze the effects of a single session of resistance training on aortic BP in PAD patients. Methods: This randomized, crossover, controlled trial involved 16 patients. All of them performed a session of resistance training ( $R-3 \times 10$ reps in eight exercises, 5-7 on the OMNI Scale) and a control session ( $C$ - resting for $50 \mathrm{~min}$ ). Before and after each session, aortic BP was assessed by applanation tonometry technique. Results: There was an increase in systolic $(P<0.002)$ and mean $(P<0.001)$ aortic BP in both sessions; however, higher increases were observed in C session $(P<0.001)$. Additionally, diastolic aortic BP only increased after $C$ session $(P=0.004)$. The hypotensive effect of the exercise on systolic, diastolic, and mean aortic BP were $-12 \pm 2,-6 \pm 2$, and $-7 \pm 2 \mathrm{mmHg}$, respectively. Conclusion: A single session of resistance training promoted a hypotensive effect on aortic $B P$ of patients with $P A D$, indicating an acute reduction in cardiovascular risk in this population. Level of Evidence I; Therapeutic studies - Investigating the results of treatment.
\end{abstract}

Keywords: Intermittent claudication; Exercise; Resistance training; Cardiovascular system; Blood pressure.

\section{RESUMO}

Introdução: Uma única sessão de treinamento de resistência reduz a pressão arterial (PA) braquial em pacientes com doença arterial periférica (DAP). No entanto, não se sabe se respostas semelhantes ocorrem na PA aórtica, queéconsiderada um melhor preditor de eventos cardiovasculares. Objetivo: Este estudo visou analisar os efeitos de uma sessão de treinamento de resistência sobre a PA aórtica de pacientes com DAP. Métodos: Esteestudo randomizado, cruzado e controlado envolveu 16 pacientes. Todos realizaram uma sessão experimental de treinamento de resistência: sessão forç̧a (SF- três séries de 10 repetições em oito exercícios, intensidade de cinco a sete na escala de OMNI-Res) e uma sessão controle (SC-repouso por 50 minutos). Antes e depois de cada sessão, a PA aórtica foi avaliada pela técnica de tonometria de aplanação. Resultados: Houve um aumento na PA aórtica sistólica $(P<0,002)$ e média $(P<0,001)$ nas duas sessões, entretanto, aumentos maiores foram observados na SC $(P<0,001)$. Além disso, a PA aórtica diastólica só aumentou após a SC $(P=0,004)$. O efeito hipotensor do exercício sobre a PA aórtica sistólica, diastólica e média foi de -12 $\pm 2,-6 \pm 2, e-7 \pm 2 \mathrm{mmHg}$, respectivamente. Conclusão: Uma única sessão de treinamento de resistência promoveu efeito hipotensor na PA aórtica de pacientes com DAP, indicando uma redução aguda do risco cardiovascular nessa população. Nível de Evidência Nível l; Estudos terapêuticos - Investigação dos resultados do tratamento.

Descritores: Claudicação intermitente; Exercício; Treinamento de resistência; Sistema cardiovascular; Pressão sanguínea.

\section{RESUMEN}

Introducción: Una sola sesión de entrenamiento de resistencia reduce la presión arterial (PA) braquial de pacientes con enfermedad arterial periférica (EAP). Sin embargo, no se sabe si respuestas similares ocurren en la PA aórtica, que es considerada un mejor predictor de eventos cardiovasculares. Objetivo: Este estudio tuvo como objetivo analizar los efectos de una sesión de entrenamiento de resistencia sobre la PA aórtica de pacientes con EAP. Métodos: Se trata de un estudio aleatorizado, cruzado y controlado que involucró a 16 pacientes Todos realizaron una sesión experimental de entrenamiento de resistencia: sesión de fuerza (SF-tres series de 10 repeticiones en ocho ejercicios, intensidad de cinco a siete en la escala de OMNI-Res) y una sesión de control (SC - reposo por 50 minutos). Antes y después de cada sesión, la PA aórtica fue evaluada por la técnica de tonometría de aplanación. Resultados: Hubo un aumento en la PA aórtica sistólica $(P<0,002)$ y media $(P<0,001)$ en las dos sesiones, sin embargo, se observaron aumentos mayores en la SC $(P<0,001)$. Además, la PA aórtica diastólica sólo aumentó después de la SC ( $P=0,004)$. El efecto hipotensor del ejercicio sobre la PA aórtica sistólica, diastólica y media fue de $-12 \pm 2,-6 \pm 2 y-7 \pm 2 \mathrm{mmHg}$, respectivamente. Conclusión: Una sola sesión deentrenamiento de resistencia promovió efecto hipotensor en la PA aórtica de pacientes con EAP, indicando una reducción aguda del riesgo cardiovascular en esa población. Nivel de Evidencia l; Estudios terapéuticos - Investigación de los resultados del tratamento.

Descriptores: Claudicación intermitente; Ejercicio; Entrenamiento de resistencia; Sistema cardiovascular; Presión sanguínea. 


\section{INTRODUCTION}

Peripheral artery disease (PAD) patients present a high prevalence of hypertension and increased risk of fatal and non-fatal cardiovascular events. ${ }^{1}$ Therefore, interventions to manage hypertension, and consequently, reduce cardiovascular risk have been targeted for these patients.

Resistance exercise has been recommended as alternative strategy for PAD, and studies showed positive effects on leg strength and walking capacity. ${ }^{2}$ Additionally, acute benefits on cardiovascular system have been previously showed with reduction in a brachial blood pressure (BP) on recovery period for up to 60 minutes after a single bout of resistance exercise. ${ }^{3,4}$ Thus, these results suggest that resistance exercise acutely reduces cardiovascular risk in PAD patients.

Although BP is conventionally measured over the brachial artery, some studies showed that aortic BP provides a better indicator of cardiovascular risk. 5,6 Thus, whether a single bout of resistance exercise promotes acute benefits on aortic BP in PAD patients is unknown. Thus, this study aimed to analyse the effect of a single bout of resistance exercise on aortic BP in PAD patients.

\section{MATERIAL AND METHODS}

Patients with PAD and symptoms of intermittent claudication were recruited from public hospitals and private vascular clinics. They were submitted to a medical history evaluation, performed a graded treadmill test until maximal claudication pain, and had their ankle and arm systolic BP measured to calculate ankle brachial index. The inclusion criteria were: a) stage II of PAD in one or both lower limbs; b) hypertensive with systolic and diastolic BP levels controlled < 160 and $105 \mathrm{mmHg}$, respectively; c) $>45$ years of age; d) postmenopausal without hormone therapy replacement, if female; e) able to walk on treadmill for at least two minutes at $3.2 \mathrm{~km} / \mathrm{h}$ and $0 \%$ of inclination; $\mathrm{f}$ ) no bypass surgery or angioplasty in the last year; g) no symptoms of myocardial ischemia during the treadmill test; $h$ ) body mass index $\leq 35 \mathrm{~kg} / \mathrm{m}^{2}$, and; i) no amputated limbs. They were excluded if they could not complete the experimental sessions, had changed their medication during the study or presented health problems.

The procedures were in accordance with the ethical standards and were approved by The Human Research Ethics Committee of the University (Protocol: CAAE 0265.0.097.000-10). Each patient was informed of the risks and benefits involved in the study, and signed a written informed consent for participation.

\section{Pre-experimental procedures}

Prior to the experiments, patients underwent two familiarization sessions designed to standardise resistance exercises execution. In these sessions, they performed the following exercises: bench press, leg press, seated row, knee extension, frontal rise, knee curl, arm curl, and hip abduction. In each exercise, three sets of 10 repetitions with the minimum load allowed by the machines were performed. Subsequently, patients performed one repetition maximum test in seated row and knee extension exercises in order to perform the anchoring procedures of OMNI resistance exercise scale.? This procedure involves submitting the patient to the lowest and highest load as possible on each exercise, in order to be able to interpret lower and higher perceived exertion. ${ }^{8}$

Afterwards, patients underwent two more sessions to identify the load to be used in the experimental sessions. In these sessions, the load corresponding to a rate of perceived exertion between five and seven ("somewhat hard") on the OMNI resistance exercise scale was determined for each resistance exercise, as previously described. ${ }^{9}$

\section{Experimental sessions}

All patients underwent two experimental sessions conducted in a simple random order by www.randomizer.org: control and resistance exercise. Each session was conducted in the morning, and an interval of at least two days was kept between them. Before the experimental sessions, patients were instructed to have a light meal and to avoid exercise, alcohol and caffeine ingestion, and smoking.
In each experimental session, patients rested in the supine position (pre-intervention). After ten minutes, aortic BP was obtained. Then, patients went to the exercise room, where they rested in the control session or exercised in the resistance exercise bout. Patients were blinded to which session they were going to perform until the beginning of the intervention.

In the resistance exercise bout, patients performed three sets of 10 repetitions of the aforementioned eight resistance exercises with a workload of five to seven on the OMNI resistance exercise scale, which corresponded to $60 \%$ of one-repetition maximum intensity. Intervals of 90 seconds were interspersed between the sets and the exercises. In the control session, patients remained resting at the exercise machines for $50 \mathrm{~min}$.

After control and resistance exercise bout, patients returned to the laboratory, where they remained resting in the supine position (post-intervention). During this period, after ten minutes of rest, the same measures obtained in the pre-intervention period were performed. All measurements were performed by a single blinded observer.

Aortic BP was estimated in the radial artery using applanation tonometry technique (Sphygmocor, ATCOR Medical, Australia). This indirect method calculate central pressure waveform and ascending aorta pressure values based on a transfer function calibrated using brachial systolic and diastolic BP values, assessed by a mercury column sphygmomanometer (Missouri, Brazil) and a stethoscope (Premium, Brazil). It was adopted 11 seconds of radial BP recording and by this data the Sphygmocor ${ }^{\circledR}$ software (Sphygmocor, ATCOR Medical, Australia) derivate the aortic BP equivalent as an invasive catheter. ${ }^{10}$ This measurement has been already used in PAD patients ${ }^{11}$ and the intraclass correlation coefficient of aortic systolic, diastolic and mean BP were $0.875,0.888$ and 0.878 , respectively between both pre-intervention days. Aortic BP was measured in supine position in pre-intervention period (10 min rest) and in post-intervention period (10 min after control or exercise session)

\section{Statistical analysis}

The Gaussian distribution and the homogeneity of variance of the data were confirmed by Shapiro-Wilk and Levene tests. Comparisons of pre-intervention values and the changes ( $\Delta=$ post-pre values) in the sessions were performed using paired t-test. Comparisons between pre- and post-condition values in each session were performed by a two-way ANOVA for repeated measurements. Post-hoc of Newman-Keuls was performed. The data are presented as mean \pm standard error and a $P$ value $\leq 0.05$ was accepted as significant.

\section{RESULTS}

Twenty-three patients were recruited, but three declined to participate. Twenty patients underwent the pre-experimental evaluations; however, four were excluded due to a health problem, osteoarticular problem, and schedule incompatibility. The characteristics of the sixteen patients included in the study are shown in Table 1. They were mostly elderly and female.

Aortic systolic, diastolic and mean BP were similar at pre-intervention sessions ( $P>0.05$ ). Table 2 shows aortic BP values before and after the experimental sessions (resistance exercise and control). There were increases in systolic $(P<0.002)$ and mean $(P<0.001)$ aortic BP in both sessions; however, greater increases were found after the control session $(P<0.001)$. Additionally, diastolic aortic BP only increased after the control session $(P<0.004)$.

Figure 1 shows mean variations ( $\triangle=$ pre - post) of each experimental session and the effect of the resistance exercise bout (net effect $=\Delta$ resistance exercise - $\triangle$ control). The increases in systolic $(P<0.001)$, diastolic $(P<0.004)$ and mean $(P<0.001)$ BP were higher in control session compared to resistance exercise session. The mean net effect were $-13 \pm 2,-6 \pm 2$, and $-8 \pm 2 \mathrm{mmHg}$ for systolic, diastolic, and mean aortic BP, respectively.

\section{DISCUSSION}

The novel finding of the present study was that resistance exercise attenuated the increases in aortic BP observed when circadian variations are taken into account in a control session. The hypotensive effect of resistance exercise provides evidence that this modality of exercise might be useful to promote a decrease in aortic BP in PAD patients. 
Table 1. Characteristics of the patients $(n=16)$.

\begin{tabular}{c|c}
\hline & Values \\
\hline Male/female & $6 / 10$ \\
\hline Age (years) & $68.1 \pm 2.2$ \\
\hline Weight (kg) & $66.3 \pm 3.1$ \\
\hline Height (m) & $1.56 \pm 0.02$ \\
\hline Body mass index (kg/m²) & $27.1 \pm 1.0$ \\
\hline Brachial systolic BP $(\mathrm{mmHg})$ & $125 \pm 4$ \\
\hline Brachial diastolic BP (mmHg) & $68 \pm 2$ \\
\hline Heart rate (bpm) & $76 \pm 3$ \\
\hline Ankle brachial index & $0.68 \pm 0.04$ \\
\hline Cardiovascular risk factors & 100.0 \\
\hline Hypertension (\%) & 43.8 \\
\hline Diabetes (\%) & 37.5 \\
\hline Dyslipidemia (\%) & \\
\hline Medication & 50.0 \\
\hline Inhibitor of angiotensin-converting enzyme (\%) & 31.3 \\
\hline Angiotensin-receptor antagonist (\%) & 56.3 \\
\hline Calcium channel blocker (\%) & 37.5 \\
\hline Diuretic (\%) & 62.5 \\
\hline Peripheral vasodilator (\%) &
\end{tabular}

Table 2. Aortic blood pressure responses to resistance exercise ( $n=16)$.

\begin{tabular}{|c|c|c|c|c|c|c|c|}
\hline \multirow{2}{*}{$\begin{array}{c}\text { Aortic BP } \\
(\mathrm{mmHg})\end{array}$} & \multicolumn{3}{|c|}{ Resistance exercise } & \multicolumn{3}{|c|}{ Control } & \multirow{2}{*}{$P$} \\
\hline & Pre & Post & $\Delta$ & Pre & Post & $\Delta$ & \\
\hline Systolic & $124 \pm 4$ & $129 \pm 5^{\dagger}$ & $5 \pm 3$ & $123 \pm 4$ & $140 \pm 5^{\text {t未}}$ & $17 \pm 3$ & $<0.001$ \\
\hline Diastolic & $72 \pm 3$ & $75 \pm 3$ & $3 \pm 1$ & $70 \pm 2$ & $78 \pm 3^{+\ddagger}$ & $8 \pm 1$ & 0.004 \\
\hline Mean & $93 \pm 3$ & $97 \pm 3^{\dagger}$ & $4 \pm 2$ & $91 \pm 2$ & $102 \pm 3^{t \neq}$ & $11 \pm 2$ & $<0.001$ \\
\hline \multicolumn{8}{|c|}{$\begin{array}{l}\text { Data presented as mean } \pm \text { standard error. 'Difference from pre-intervention; ;Difference from the resistance } \\
\text { exercise bout. }\end{array}$} \\
\hline 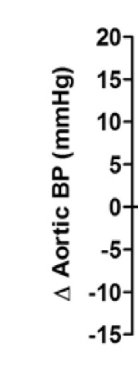 & $<0.001$ & & & & $\begin{array}{l}\text { Resi } \\
\text { 口 Cont } \\
\text { Net } \mathrm{e}\end{array}$ & $\begin{array}{l}\text { ance Exe } \\
\text { ect }\end{array}$ & \\
\hline
\end{tabular}

Figure 1. Mean variations of resistance exercise (black bars), control conditions (white bar) and the net effect (gray bar). P values indicate difference from resistance exercise bout.
Central aortic systolic and diastolic pressures are determinants of cardiac loading and perfusion, and they impact importantly on cardiovascular function. ${ }^{12}$ Patients with PAD present worse profile of the aortic $\mathrm{BP}$ in comparison with age-matched controls. In fact, previously study showed that aortic BP was higher in PAD patients (systolic: 135.7 \pm 19.2 vs. $117.8 \pm 12.6 \mathrm{mmHg}$; diastolic: $82.3 \pm 10.9$ vs. $78.2 \pm 9.1 \mathrm{mmHg} ; P<0.01) .^{11}$ Thus, strategies to decrease aortic BP are necessary with aim to reduce cardiovascular load in these patients. ${ }^{6}$

In the present study, after resistance exercise, there was a hypotension effect in systolic, diastolic, and mean aortic BP with net effects of $-13 \pm 2$, $-6 \pm 2$, and $-8 \pm 2 \mathrm{mmHg}$, respectively. In contrast, other studies showed maintenance ${ }^{13,14}$ or increases immediately on aortic $\mathrm{BP}^{15,16}$ after resistance exercise in healthy or hypertensive subjects. Different results after exercise on aortic BP could be explained by distinct populations evaluated. In fact, individuals clinically worse in terms of health status seem to respond better acutely to exercise. ${ }^{17}$ The BP hypotension after resistance exercise in PAD patients were also observed in brachial artery up to 60 minutes s, $^{3,18}$ but it was not maintained under ambulatory conditions. ${ }^{4}$ Given that the hypotension are observed in both aortic and brachial measures, 3,4,18 it is plausible to suggest that the effect of resistance exercise is clinical in these patients.

From a practical point of view, taken together brachial and aortic BP hypotension, resistance exercise must be reinforced to be used as alternative exercise strategies to promote reduction in cardiovascular risk in PAD patients. Some limitations need to be considered. The patients were using different drug therapy that probably had influence on cardiovascular responses. Additional analysis of the influence of medication on these responses cannot be performed. Patients were monitored for only $60 \mathrm{~min}$ and so it was not possible to determine the duration of the responses. Finally, chronic effects of resistance exercise on aortic BP must investigated in future studies

\section{CONCLUSION}

As a conclusion, a single bout of resistance exercise promotes a hypotensive effect on aortic BP in patients with PAD, indicating an acute reduction on cardiovascular risk in this population.

\section{ACKNOWLEDGEMENTS}

Conselho Nacional de Desenvolvimento Científico e Tecnológico (CNPq), Coordenação de Aperfeiçoamento de Pessoal de Nível Superior (CAPES), Fundação de Amparo a Ciência e Tecnologia de Pernambuco (FACEPE), and Pronto Socorro Cardiológico de Pernambuco (PROCAPE)

All authors declare no potential conflict of interest related to this article.

AUTHORS' CONTRIBUTIONS: Each author made significant individual contributions to this manuscript. RMRD (0000-0001-7883-6746)* and GGC (0000-0002-2060-8853)* carried out the design and coordinated the study; MAC (0000-0002-8983-3433)* and AHG (0000-0003-0327-4739)* performed the data collection, monitored patients and supervised the sessions; MAC (0000-0002-8983-3433)*, AA (0000-0002-8559-7752)* and RMRD (0000-0001-7883-6746)* were the main contributors to the writing and discussion of the manuscript; MAC (0000-0002-8983-3433)*, AHG (0000-0003-0327-4739)* and RMRD (0000-0001-7883-6746)* evaluated the data of the statistical analysis; and GGC (0000-0002-2060-8853)* and ECC (0000-0003-2807-7109)* performed the critical review of the manuscript and contributed to the intellectual concept of the study. All authors reviewed and approved the final version of the manuscript. *ORCID (Open Researcher and Contributor ID).

\section{REFERENCES}

1. Weitz J, Byrne J, Clagett GP, Farkouh ME, Porter JM, Sackett DL, et al. Diagnosis and treatment of chronic arterial insufficiency of the lower extremities: a critical review. Circulation. 1996;94(11):3026-49.

2. Menêses $A L$, Farah BQ, Ritti-Dias RM. Função muscular em indivíduos com doença arterial obstrutiva periférica: uma revisão sistemática. Motricidade. 2012;8(1):86-96

3. Cucato GG, Ritti-Dias RM, Wolosker N, Santarem JM, Jacob Filho W, Forjaz CL. Post-resistance exercise hypotension in patients with intermittent claudication. Clinics, 2011:66(2):221-6.

4. Rodrigues LB, Forjaz CL, Lima AH, Miranda AS, Rodrigues SL, Cardoso CG Jr., et al. A single bout of resistance exercise does not modify cardiovascular responses during daily activities in patients with peripheral artery disease. Blood Press Monit. 2014;19(2):64-71.

5. Williams B, Lacy PS, Thom SM, Cruickshank K, Stanton A, Collier D, et al. Differential impact of blood pressure-lowering drugs on central aortic pressure and clinical outcomes: principal results of the Conduit Artery Function Evaluation (CAFE) study. Circulation. 2006:113(9):1213-25.

6. Pini R, Cavallini MC, Palmieri V, Marchionni N, Di Bari M, Devereux RB, et al. Central but not brachial blood pressure predicts cardiovascular events in an unselected geriatric population: the ICARe Dicomano Study. J Am Coll Cardiol. 2008;51(25):2432-9.

Lagally KM, Robertson RJ. Construct validity of the OMNI resistance exercise scale. J Strength Cond Res. 2006;20(2):252-6.

8. Dias RM, Cucato GG, Câmara LC, Wolosker N. Reprodutibilidade do teste de 1-RM em indivíduos com doença arterial obstrutiva periférica. Rev Bras Med Esporte. 2010;16(3):201-4.

9. Gearhart RE, Goss FL, Lagally KM, Jakicic JM, Gallagher J, Robertson RJ. Standardized scaling procedures for rating perceived exertion during resistance exercise. J Strength Cond Res. 2001;15(3):320-5.
10. Siebenhofer A, Kemp C, Sutton A, Williams B. The reproducibility of central aortic blood pressure measurements in healthy subjects using applanation tonometry and sphygmocardiography. J Hum Hypertens. 1999;13(9):625-9.

11. Zagura M, Kals J, Serg M, Kampus P, Zilmer M, Jakobson M, et al. Structural and biochemical characteristics of arterial stiffness in patients with atherosclerosis and in healthy subjects. Hypertension Res. 2012:35(10):1032-7.

12. Trudeau L. Central blood pressure as an index of antihypertensive control: determinants and potential value. Canadian Journal of Cardiology. 2014;30(5 Suppl):S23-8

13. Yoon ES, Jung SJ, Cheun SK, Oh YS, Kim SH, Jae SY. Effects of acute resistance exercise on arterial stiffness in young men. Korean Circ J.. 2010;40(1):16-22.

14. Okamoto T, Min S, Sakamaki-Sunaga M. Arterial compliance and stiffness following low-intensity resistance exercise. Eur J Appl Physiol. 2014;114(2):235-41.

15. Lefferts WK, Augustine JA, Heffernan KS. Effect of acute resistance exercise on carotid artery stiffness and cerebral blood flow pulsatility. Frontiers Physiol. 2014;5:101.

16. Lydakis C, Momen A, Blaha C, Gugoff S, Gray K, Herr M, et al. Changes of central haemodynamic parameters during mental stress and acute bouts of static and dynamic exercise. J Human Hypertens. 2008;22(5):320-8.

17. Melo CM, Alencar Filho AC, Tinucci T, Mion D Jr., Forjaz CL. Postexercise hypotension induced by low-intensity resistance exercise in hypertensive women receiving captopril. Blood Press Monit. 2006;11(4):183-9.

18. Correia MA, Soares AH, Cucato GG, Lima AH, Gomes AP, Prazeres TM, et al. Vascular mechanisms of postexercise blood pressure responses in peripheral artery disease. Int J Sports Med. 2015;36(13):1046-51 